Let sleeping dogs lie

\section{Palmer Station}

ThE trouble with Antarctic tourists is that there are not enough of them. And they are too well behaved. If tourists were swarming the rocky shores of Antarctica, poking at penguins and leaving film wrappers behind, there would no doubt be world outrage and calls for restrictions. But that is not the case, and the National Science Foundation (NSF), which runs the US programme, is left in a quandary. The number of visitors is still manageable - fewer than 2,000 last year and reports of serious abuses are virtually nonexistent. That could change, but until it does, NSF is hesitant to jump the gun with draconian regulations.

"The problem", says Polly Penhale, Antarctic programme officer at the NSF, "is mostly potential." Tour companies now work closely - and voluntarily with NSF to coordinate visits, ensuring that the ships neither pile up at Palmer Station nor overvisit the most popular penguin rookeries. Relations have become so chummy that Penhale, who gives lectures to the tourists when she is at Palmer, has become internationally Wish you were here? The lucky survivors from the Bahia Paraiso arrive at Palmer known for the cakes she serves Station. (Photo:NSF/Ted Delaco) the visitors.

The cruise ships usually have trained scientists on board to give lectures and to make sure that tourists obey the laws of the Antarctic Treaty - do not approach animals, do not take anything, do not leave anything, and so on. But the tourists seem to need few reminders. With an average of some $\$ 8,000$ per person invested in the trip, they tend to be well informed, scientifically and ecologically literate and respectful of the continent.

"So far, so good", says Penhale. Her worry is there may eventually be less responsible operators. NSF's policy is neither to encourage nor discourage tourism. Its attempt, in 1989 , to ban tourism at US stations provoked complaints from spurned visitors, who argued that they had a right to see the way their tax money was being spent, which forced the NSF to reverse its decision.

Beyond environmental issues, there is a question of whether the United States is

\section{IMAGE UNAVAILABLE FOR COPYRIGHT REASONS}

New Zealand DC-10 that hit a mountain in 1979 , the US court of appeals ruled that the United States did have a legal responsibility in Antarctica (although the court did not find negligence in that particular case). But in a subsequent Californian decision, a district judge ruled that the United States could not be held liable for the deaths of two US contractors who fell down a crevasse.

"It's an open legal issue", says Lawrence Rudolph, deputy general counsel at NSF. Rather than fight lawsuits case by case in the future, NSF has asked the Justice Department to clarify the Tort Claims Act to include Antarctica as a 'foreign country', exempt from suits. Meanwhile, many NSF contractors have taken out personal liability insurance, for fear that they themselves will be sued even if the government cannot be.

So, without a clear policy on tourism and an unclear legal position, NSF gingerly waits to see what will happen next. If visitors to the Antarctic stay at the level of several thousand each year and tour operators continue to work with government officials to minimize the effect on the environment, restrictions may not be necessary. But the lessons of the Bahia Paraiso are still a fresh warning of where thing can go wrong. When the Argentine sup- liable for damage suffered by tourists. Although the US Tort Claims Act offers the government protection from suits for damage suffered in foreign countries, Antarctica is not considered a country and is not subject to that exemption. Legal precedent, meanwhile, is clouded by two contradictory court decisions. In one case, brought by the families of some of 257 victims of the Air ply ship went aground in 1989 with 85 tourist aboard, it happened to be less than a mile from Palmer, whose staff were able to rescue everybody on board.

Had it been just a few miles further away, the situation might have been very different. When the inevitable next accident happens, the future of Antarctic tourism may hang in the balance.

ANTARCTIC researchers, like any isolated group, have developed their own home-brewed vocabulary, for all the usual reasons as well as to spot the 'fingies' (see below). The derivations of the following Antarctic idioms are speculative at best, and their meanings tend to change somewhat with time, but the list can be considered relatively up to date.

When they say... They mean....

BEAKER

BLACK TIE

FINGIE

THE ICE

HEY, IT'S A HARSH

CONTINENT

DIAPERS

ANTARCTIC 10

BUNNY BOOTS

SKUA

SLIDERS

CHICKEN COOKIES Frozen chicken patties, sometimes mistaken momentarily for dessert.

\section{Talk like a beaker}

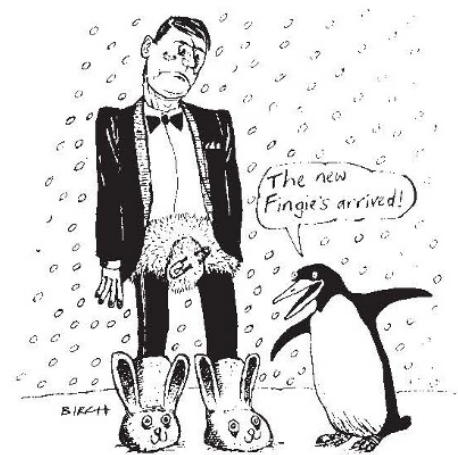

COUNTRY MICE

CITY MICE

HOUSE MICE
CHINESE LANDING A phonetic pun, based on the usual aircraft angle when landing in stiff Antarctic cross winds: one wing low.

A Navy term, derisively used to describe showers of longer than the allotted two minutes.

The routine of carrying one's NSF-issue bag of polar clothing to the airstrip, only to find that the notoriously unpredictable Antarctic weather has once again halted all flights for 24 hours.

Scientists and their assistants who get to travel to camps around Antarctica. Support personnel whose duties force them to remain at McMurdo Station.

Personnel on periodic janitorial duty. 